\title{
Social entrepreneurship as a catalyst to break the poverty trap: An analysis of the motivational factors in South Africa
}

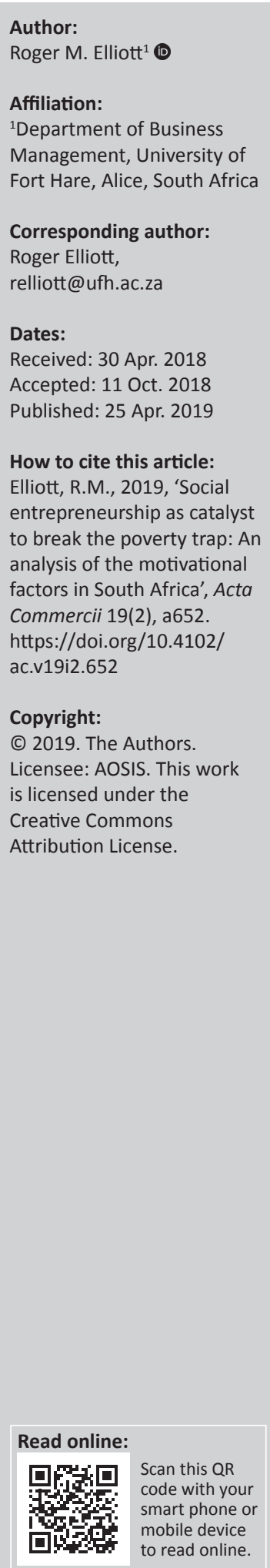

Orientation: Social entrepreneurship has been advocated as a way of overcoming poverty but many of the studies purporting to explain the intention to become a social entrepreneur have resulted in inconsistent and inconclusive results.

Research purpose: The purpose of this article was to examine the moderating influence of gender, family entrepreneurial background and culture (operationalised in this study as individualism or collectivism) on the antecedents to the formation of an intention to become a social entrepreneur in respect of financially disadvantaged students.

Motivation for the study: Educational institutions in Africa have not implemented programmes to encourage students to become social entrepreneurs.

Research design, approach and method: A questionnaire survey was conducted using a convenience sampling method in which a sample of 200 students was selected from a South African university. The data were analysed using hierarchical regression analysis.

Main findings: Results provide strong support for the proposition that students' gender and culture moderate the impact of the antecedents identified in this study (being close to the social problem and innovative) on the intention to become a social entrepreneur.

Practical/managerial implications: There needs to be more collaboration and dialogue within and across all South African universities so that all educational programmes can be developed that embrace the challenges face by contemporary South African society.

Contribution/value-add: This article demonstrates that current intention-based models are not adequate to explain the intention to become a social entrepreneur as they exclude extraneous personal and environmental factors.

Keywords: South Africa; social entrepreneurship; intention; gender; culture; entrepreneurial background.

\section{Introduction}

Entrepreneurship has been proposed as an engine for economic development in Africa (Acs 2006; Halcombe 1998; Toma, Grigore \& Marinescu 2014) because of its potential to create wealth and employment for (economically disenfranchised) individuals (Manyaka 2015; Memani \& Fields 2014; Soomro \& Shah 2015). Although the benefits of commercial (or traditional) entrepreneurship are well documented (Van Praag \& Versloot 2007), the driving force of these enterprises is usually focused exclusively on making a profit, with little concern for the broader social impact of the enterprises (Toma et al. 2014). In addition, Nyström (2009) argues that the broader developmental benefits of traditional entrepreneurship are overstated with some (Nga \& Shamuganathan 2010) going further and stating that the short-term and selfish focus of many commercial entrepreneurs will inevitably lead to economic recession, decreasing social livelihood levels and environmental degradation. Rather, Nga and Shamuganathan (2010) propose that entrepreneurs should implement integrative business models that encompass economic, social and environmental values that are typical of social enterprises.

The focus on social entrepreneurship has been given additional emphasis by the realisation that the non-governmental organisations (NGOs), usually funded by donations and not driven by profit, have been unsuccessful in the eradication of poverty (Rametse \& Shah 2013). Compounding this problem is that donors, who traditionally funded these non-profit organisations, are increasingly suffering from 'donor fatigue' (Smith, Cronley \& Barr 2012). Consequently, social 
entrepreneurship has been viewed as an alternative model to meet the needs of the marginalised and the vulnerable, where the social entrepreneur focuses on both a financial and a social 'bottom line'. However, one of the problems associated with understanding the importance of this business model in overcoming the challenges of poverty and economic equality on the African continent is the lack of consensus on what is meant by social entrepreneurship (Mair \& Marti 2006; Zahra et al. 2009). Urban and Teise (2015) define social entrepreneurship as a process of value creation through the combination of resources with the intention of exploiting opportunities to create social value, while Germak (2013) emphasises social entrepreneurship's triple bottom line of improving social conditions, community outcomes and financial objectives. In this study, social entrepreneurship is defined as an innovative, sustainable and permanent problem-solving entrepreneurial initiative in response to a social or environmental problem (Irengun \& Arikboga 2015).

Although the majority of research (on social entrepreneurship) has taken place in developed countries like the United States and Canada (Irengun \& Arikboga 2015; Mair \& Marti 2006), there have been some studies on social entrepreneurship in emerging markets such as South Africa (Urban \& Teisse 2015). However, South Africa has a dual economy, with the first economy being comparable to many 'developed' countries, whereas the second economy is characterised by poverty, unemployment and exclusion. In addition, South Africa has one of the highest inequality rates in the world, with the poorest $20 \%$ of the inhabitants consuming less than $3 \%$ of total expenditure, whereas the wealthiest $20 \%$ consuming $65 \%$ of total expenditure (World Bank 2017).

Defining what is meant by poverty is no easy matter (Woolard \& Leibbrandt 1999) as the concept of poverty is nebulous (Nattrass \& Seekings 2001). Understanding this concept is important as one of the arguments why (social) entrepreneurship will not succeed in uplifting marginalised communities is the concept of the 'poverty trap'. This assertion is based on the belief that (social) entrepreneurship is not accessible to 'economically poor' individuals as a development tool because of the lack of access to finance (Odhiambo 2009) to start business. However, an alternative view is that one of the constraints to the formation of an intention to become a (social) entrepreneur is an individual's perceptions of their economic situation, relative to their peers. This is because perceived poverty will impact the nature and extent of the motivational factors driving the intention to become a (social) entrepreneur (Irengun \& Arikboga 2015; Krueger, Reilly \& Carsrud 2000).

Education is seen as an important enabler for breaking the cycle of poverty by encouraging the growth of (social) entrepreneurs (Herrington, Kew \& Kew 2010), although the South African tertiary education system is seen as a significant obstacle as it does not meet the needs of their particular cohort of students (Illingworth 2015; Lazenby \& Machaba 2011; Mahadea, Ramroop \& Zevvotir 2011). This is because although apartheid was officially abolished in 1994, the economic divide entrenched by years of this policy is still mirrored in the tertiary education system of South Africa, where students from economically marginalised communities tend to gravitate towards 'historically disadvantaged universities' (HDIs). For example, in 2016, 91\% of students at the University of Fort Hare qualified to receive National Student Financial Aid Scheme (NSFAS) funding, meaning that the families of the students earned less than R122 000 per annum (Tom 2016). However, many of the quantitative studies into the antecedents of the intention to become a social entrepreneur (and traditional entrepreneur) have been conducted using a population from traditionally advantaged (white) universities (Gird \& Bagraim 2008; Urban \& Teisse 2015) as opposed to HDIs. This is an important distinction given the importance of culture (Hayton, George \& Zahra 2002), entrepreneurial family background and gender (Bruton \& Ahlstrom 2003; Hofstede 2001; Karhunen \& Ledyaeva 2010) in choosing a career path as do childhood experiences such as poverty and financial difficulties (Krueger et al. 2000; Wu, Matthews \& Dagher 2007). Consequently, these studies have limited value informing HDIs universities and other similar tertiary institutions about how programmes should be structured.

As such the research question is as follows: to what extent do culture, gender and an entrepreneurial family culture moderate the antecedents to form a social entrepreneurial intention in HDIs? In addition, this study focuses on undergraduate students, as opposed to the studies of Urban and Teisse (2015) and Germak and Robinson (2014), as we argue that, more so than postgraduate students and employed people, undergraduate students stand at the crossroads of their career. Therefore, this study addresses the shortcomings in existing studies and literature by empirically identifying the moderating factors and the antecedents that might impact the intention to become social entrepreneur.

\section{Literature review}

The focus of the literature review firstly considers the intention-based model thereafter, the drivers (or antecedents) of the intention to engage in social entrepreneurship. The factors that moderate these relationships are considered and importantly culture is operationalised as the individualism/ collectivism dimension.

\section{Intention}

Social entrepreneurship intention can be understood as a conscious awareness and conviction to set up a new (social) business venture (Bird 1988; Irengun \& Arikboga 2015; Urban \& Teisse 2015; Zahra et al. 2009). This concept is important because of the well-established link between the intention to perform a particular action and the actual behaviour (Ajzen 1988; Krueger et al. 2000). Importantly, for the purposes of this study, intentions capture the motivational factors that ultimately result in the behaviour (Ajzen 1991).

There are a number of theories that offer a theoretical base to understand the drivers of intention (to become a social 
entrepreneur), such as the Theory of Planned Behaviour (TPB) (Ajzen 1991), the Social Entrepreneurial Event Model (SEE) (Shapero \& Sokol 1982) and the Model of Implementing Entrepreneurial Ideas (IEI) (Bird 1988). All these theories assume that perceptions serve as the primary justification for the formation of an intention.

\section{Antecedents}

Although many studies have used these underpinning (intention-based) theories as the basis to study entrepreneurial activity (Gird \& Bagraim 2008), others (e.g. Carsrud \& Brannback 2011; Cope 2005; Nga \& Shamuganathan 2010; Soomro \& Sha 2015) have focused on personality (an individual's psychological traits), functional (economic outcomes) and behavioural factors (how an entrepreneur sees and acts upon the opportunities). Nevertheless, there are a number of recurring themes in the efforts to identify the antecedents to the formation of an entrepreneurial intention which is the focus of this study.

\section{Closeness to social problem}

One of the critical factors in being a successful entrepreneur is being able to identify a need, which in the case of many social entrepreneurs is being close to the social problem (Germak \& Robinson 2014). This does not necessarily suggest spatial closeness to the problem as technology, and the rise in global citizenry has made this type proximity less important (Bornstein \& Davis 2010). Although being close to a social problem suggests having knowledge of a social or environmental problem, such as social workers (Germak \& Robinson 2014), it may also include instances where an individual has 'first-hand', rather than remote, knowledge and has endured some financial or social hardship as a child (Drennan, Kennedy \& Renfrow 2015). The link between this construct and the intention to start a social entrepreneurial venture is consistent with social problems theory, which proposes that individuals who identify a social need are able to identify a solution to the problem, such as starting a social entrepreneurship venture (Hervieux \& Voltan 2018).

Consequently, the following hypothesis is formed:

H1: Closeness to the social problem will have a significant influence on the intention to become a social entrepreneur.

\section{Helping society}

Social entrepreneurs are typically viewed (particularly in an African context) as individuals who seek to meet a need in a (economically or socially) deprived community (Nga \& Shamuganathan 2010; Urban \& Teisse 2015) and in so doing seek to uplift that group of people and thereby help society. However, while many of the activities are aimed at disadvantaged segments of the community (Seelos \& Mair 2005), this is a somewhat narrow view of social entrepreneurship (Certo \& Miller 2008) as entrepreneurs who start enterprises that benefit advantaged segments of the community can also be defined as social entrepreneurs
(Zahra et al. 2009). Nevertheless, implicit in this factor is the dimension of empathy which implies the ability to recognise and share the feelings of others. Although this is an important element in the social entrepreneurial process, it is a 'necessary but not sufficient condition' (Mair \& Noboa 2006) to facilitate an intention to become a social entrepreneur. A further dimension of this construct is moral judgement (Urban \& Tiese 2015), which implies that social entrepreneurs are sensitive to the feelings of others (Prabhu 1999) and are able to relate to another's plight or predicament (Mair \& Noboa 2006; Miller et al. 2012). This suggests that in particular contexts social entrepreneurs will take tangible steps to overcome social problems (Johnson 2000).

Consequently, the following hypothesis is formed:

H2: Helping society will have a significant influence on the intention to become a social entrepreneur.

\section{Achievement orientation}

A need to achieve, consistent with the theory of selfactualisation proposed by Maslow (1943), is an important factor in driving the intention to become both a traditional and social entrepreneur (Baum, Frese \& Baron 2007) notwithstanding the altruistic nature of social entrepreneurship (Boluk \& Mottiar 2014; Germak 2013). This could be because social entrepreneurs see the 'return' on an entrepreneurial venture not only in financial terms, but also in terms of the difference that they can make in their communities or meeting a particular social or environmental need (Boluk \& Mottiar 2014; Soomro \& Sha 2015).

\section{Consequently, the following hypothesis is formed:}

H3: Achievement orientation will have a significant influence on the intention to become a social entrepreneur.

\section{Innovation}

Innovation is a critical element in the process of 'creative destruction' which is required to set up successful entrepreneurial ventures. Similar to their commercial counterparts, being innovative is an important attribute of social entrepreneurs (Germak \& Lehner 2013; Ionescu 2015; Praszkier \& Novak 2012), although the focus is on formulating new (innovative) ideas, products or services to meet social needs (Bouchard 2012; Germak \& Lehner 2013; Ionescu 2015; Zahra et al. 2009).

In developing countries such as South Africa, the focus of social entrepreneurship is on disadvantaged and marginalised communities (Seelos \& Mair 2005) because of their widespread poverty within a vastly unequal society (Nattrass \& Seekings 2001; Odhiambo 2009; Woolard \& Leibbrandt 1999). This implies that because of their lack of resources, social entrepreneurs need to be resourceful and imaginative in creating financially sustainable solutions to social problems (Nga \& Shamuganathan 2010; Shaw \& Carter 2007). This is because the markets in which they operate are unconventional and often deemed as high risk by traditional commercial 
entrepreneurs (Hart 2005; Nga \& Shamuganathan 2010). The foundation of this cognitive ability is a sense of personal mastery which allows social entrepreneurs to be dynamic and flexible in uncertain and ambiguous environments (Urban 2012).

Consequently, the following hypothesis is formed:

H4: Innovation will have a significant influence on the intention to become a social entrepreneur.

\section{Self-efficacy}

Self-efficacy influences thought patterns, actions and emotional arousal in people which is rooted in Bandura's (1986) social learning theory. The construct of self-efficacy is similar to the construct of perceived behavioural control contained in the TPB (Ajzen 2002, 2011), and both emphasise the link between self-belief and the intention to become both an entrepreneur (Bandura 1977; Urban 2010) and a social entrepreneur (Bagheri \& Pihie 2010; Urban \& Teise 2015).

Self-efficacy is an individual's confidence in his or her ability to perform entrepreneurial roles and tasks successfully, and perceived self-efficacy is the predictor of career choice and has been found to predict entrepreneurial intentions among individuals (Bandura 1986; Urban 2010). In many respects, self-efficacy reflects the perseverance of an individual, rather than particular skills and the belief that they will prevail over any obstacles to achieve their goals (Bandura 1997). In particular, self-efficacy has a considerable influence on individual choices, goals and emotional reactions (Bandura 2001) because it informs an individual's belief in their ability to succeed in fulfilling tasks (Urban 2015; Urban \& Teise 2015).

Consequently, the following hypothesis is formed:

H5: Self-efficacy will have a significant influence on the intention to become a social entrepreneur.

Although there has been limited research into the antecedents of entrepreneurial intention in Africa (Urban 2015; Urban \& Teise 2015), much of the research in developed nations has been inconclusive in terms finding a relationship between various antecedents and intention (Shook, Priem \& McGee 2003). Consequently, it has been suggested that a number of variables such as culture, gender (Bahrami 2014; Shinnar, Giacomin \& Janssen 2012; Triandis \& Su 2002; Urban 2007) and family background (Shittu \& Dosunmu 2014) might account for the unhelpful and inconsistent results.

\section{Moderators}

The moderating variables of culture (defined as the dimensions of individualism or collectivism for the purpose of this study), gender and the entrepreneurial background of the family are considered below.

\section{Culture}

The debate about the link between culture and the propensity to engage (in both commercial and social) entrepreneurship
(McGrath, MacMillan \& Scheinberg 1992; Urban 2007) is ongoing. The contemporary understanding of culture is based on the seminal work of Hofstede (1980) who identified four initial dimensions of culture: power distance, uncertainty avoidance, individualism or collectivism, masculinity or femininity, as well as an additional dimension - long-term or short-term orientation (Hofstede \& Bond 1988).

Although Hofstede (1980) did not consider the relationship between culture and entrepreneurship (Urban 2006), the dimension of individualism or collectivism (a continuum) is the most profound in distinguishing between cultures (Triandis \& Suh 2002) and consequently has been used as the basis for many studies exploring the link between culture and entrepreneurial behaviour (Morris, Davis \& Allen 1993; Mueller \& Thomas 2000; Pinillos \& Reyes 2011), although the results have been somewhat inconsistent.

A predominantly individualistic orientation would suggest a sense of personal responsibility which would lead to selfefficacy and self-confidence which are essential in driving innovative ideas. Although these attributes are important for both traditional (commercial) entrepreneurship and social entrepreneurship, an excess focus on individual interests may result in avaricious or selfish behaviour which is inconsistent with the altruistic foundations of social entrepreneurship. On the other hand, collectivism is characterised by amicable relationships between stakeholders, a cooperative approach and a concern for others, which are consistent with the tenets of social entrepreneurship. This (collectivist approach) is an important element of new venture creation because of the importance of being able to leverage both internal and external resources (Tiessen 1997; Urban 2007).

The nature and extent of the influence of the individualism or collectivism dimension on the extent of (both social and commercial) entrepreneurship will vary. Morris et al. (1993) proposed that countries with moderate levels of individualism will exhibit the highest levels of entrepreneurship, while Mueller and Thomas (2000) concluded that cultures with high levels of individualism (and uncertainty avoidance) are likely to be characterised by high levels of entrepreneurship. In a more recent study, Pinillos and Reyes (2011) found that the influence on the individualism on the level on entrepreneurship varied, depending on the level of development of the economy. Most studies have, however, focused on the commercial entrepreneurship and there is a void in respect of the impact of culture, defined for the purposes of this study as the individualism or collectivism continuum, on the extent of social entrepreneurship (Dacin, Dacin \& Tracey 2011). Consequently, it is argued that the extent of entrepreneurial activity cannot be explained by personal factors alone, and that culture may well have an impact on the intention to become a social entrepreneur (Pinillos \& Reyes 2011; Tiessen 1997; Urban 2007).

Consequently, the following hypothesis is formed:

H6: Culture will moderate the extent to which the antecedents (closeness to social problem, helping society, achievement 
orientation, innovation and self-efficacy) influence the intention to become a social entrepreneur.

\section{Gender}

Notwithstanding an increase in the participation of women in the commercial sphere (Fielden \& Davidson 2005) in most countries, including South Africa, women are underrepresented in the entrepreneurial and new venture formation domains (Aliaga 2006; Maas \& Herrington 2006). This is consistent with international studies that found that the propensity of women to engage in entrepreneurship will differ depending on such factors as laws, religion, culture and societal norms (Buttner \& Moore 1997; Gupta et al. 2009). These factors are, however, all underpinned by the perception that entrepreneurial careers are considered as a masculine domain (Henry, Foss \& Ahl 2016) but in some countries women are more likely to embrace a social entrepreneurship career than in others (Terjesen et al. 2009). Consequently, consistent with social role theory (Gupta et al. 2009; Shinnar et al. 2017), it is argued that gender will moderate the relationship between the antecedents (discussed above) and the formation of a social entrepreneurial intention.

Consequently, the following hypothesis is formed:

H7: Gender will moderate the extent to which the antecedents (closeness to social problem, helping society, achievement orientation, innovation and self-efficacy) influence the intention to become a social entrepreneur.

\section{Family entrepreneurial background}

Families can be a significant influence on the extent to which individuals are positively disposed to becoming an entrepreneur (Bagheri \& Pihie 2010; Birley \& Westhead 1994). Parents, and the extended family, can still play an important part in a child's entrepreneurial tendencies, even if they were not themselves entrepreneurs through emotional and intellectual support (Shen, Osorio \& Settles 2017). However, the involvement of family members (or the individual) in their own businesses will develop the nascent entrepreneur's self-confidence to initiate an entrepreneurial venture (Bagheri \& Pihie 2010; Nga \& Shamuganathan 2010). Specifically, selfemployed parents and extended family members will act as mentors and guides (Matthews \& Moser 1995; Scherer et al. 1989), and these family networks have a positive influence on the extent of innovativeness, motivation and planning for entrepreneurial ventures (Germak 2013).

\section{Consequently, the following hypothesis is formed:}

H8: Family entrepreneurial background will moderate the extent to which the antecedents (closeness to social problem, helping society, achievement orientation, innovation and self-efficacy) influence the intention to become a social entrepreneur.

\section{Research methodology}

This section considers the design of the research and the sample surveyed.

\section{Research design}

The initial step in the data analysis was to assess the discriminant validity of the instrument. This was done using the multivariate technique of exploratory factor analysis using SPSS (Version 24). The factorial load and the communality below 0.45 were defined as extraction criteria (Hair et al. 2010). To apply a factorial model, it is necessary that the correlation among variables is above 0.5 , and to check this, the Kaiser-Meyer-Olkin (KMO) test was used and reported values above acceptable thresholds. The reliability of the instrument was confirmed by calculating the Cronbach's alpha coefficients for each of the factors. Thereafter a four-stage hierarchical multiple regression was conducted to consider the relationship between the variables identified.

\section{Sampling design}

The sample was drawn from undergraduate business management students studying at a historically disadvantaged university in South Africa. This is not only consistent with previous studies, but the propensity for students studying commercial subjects to participate in different types of entrepreneurial activity is greater than among the wider student constituency (Harris \& Gibson 2008; Turker \& Selcuk 2009; Urban 2013).

A total of 200 students were surveyed, of which $54 \%$ were females and $46 \%$ males. The students were mostly undergraduates $(71 \%)$ and were either fourth-year or honours students (29\%). As expected, the respondents were relatively young, with $80 \%$ in the age group of $18-24$ years, $17.5 \%$ in the age group of $24-34$ years, whereas only five students $(2.5 \%)$ were above the age of 34 years at the time of the survey. The population group was University of Fort Hare students who are predominately from previously disadvantaged backgrounds (Tom 2106), with 90.5\% (181) describing themselves as black students, 7.5\% (15) as mixed race students and $1.5 \%$ as Asian students. Only three white students $(1.5 \%)$ completed the questionnaire. In respect of employment, 171 (85.1\%) were unemployed, 21 (10.4\%) were part-time employed, four $(1.5 \%)$ were full-time employed and three $(1.5 \%)$ were self-employed.

\section{Ethical considerations}

Ethical clearance was obtained from the ethics committee of University of Fort Hare (Reference number: MC2018-017).

\section{Results}

This section firstly considers the validity and reliability of the instruments used to measure the variables. The loading of the items on the different factor is considered after which they are operationalised and where necessary the hypotheses are reformulated. Lastly, the results of the hierarchical regression analysis are considered. 


\section{Validity and reliability}

Table 1 provides a summary of the rotated component matrix and is set out below. It includes the eigenvalues and the Cronbach's alpha coefficients associated with each of the scores. The items associated with the item codes are presented in Appendix 1. From Table 1 it is clear that all the factors recorded an eigenvalue above 1, which is consistent with both Kaiser's rule (Kaiser 1960) and the suggestion by Jolliffe (2002) who advised a more conservative cutoff eigenvalue 0.7 because it would be unwise to delete the components that have eigenvalues close to 1 .

\section{Measurement}

In the first factor identified, closeness to the social problem, only three of the original items loaded on this construct and reliability was poor, but nevertheless acceptable within the context of this study, recording a Cronbach's alpha score of 0.461 . The construct was operationalised as the extent to which people felt that poor people were honest and were no different to the rest of society. The scale was derived from the literature and, in particular, the study of Germak (2013).

Underpinning original construct of helping society is a certain amount of compassion and empathy. Consequently, the compassion scale (Raes et al. 2011) was used and adapted as a basis to measure the construct of helping society. However, the factor analysis revealed that the construct of helping society was not unidimensional and it loaded on three separate factors: helping society (connected) operationalised as the extent to which an individual has the propensity to connect with people at an emotional level when they are experiencing some sort of hardships; helping society (humanity) is operationalised as the extent to which an individual acknowledges and accepts human frailties, whereas helping society (empathy) is operationalised as the extent to which an individual can relate to poor people. All constructs demonstrated an adequate Cronbach's alpha score (0.827, 0.674 and 0.526 , respectively) and consequently can be considered reliable.

The reliability for achievement orientation was good (0.803), but one item was deleted as a result of poor loading when the

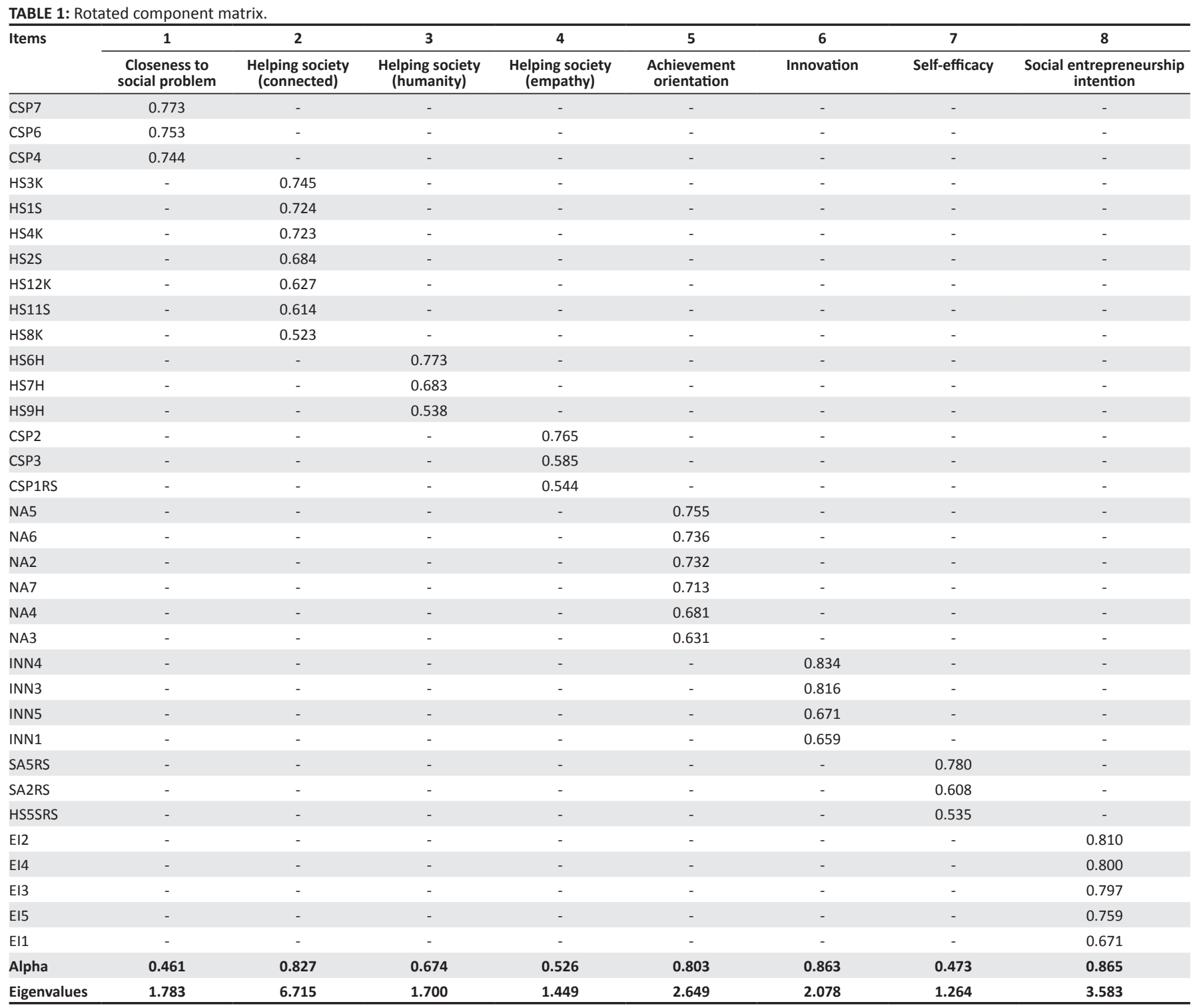


validity was assessed. Although Urban and Tiese (2015) developed an instrument to measure achievement orientation, it was adapted to make it more relevant for students who (mostly) had not participated in the job market. Consequently, achievement orientation was operationalised as the extent to which students feel the need to achieve by having a longterm vision and the perseverance to achieve long-term goals without any compromise.

Innovation is operationalised as the extent to which students are able to come up with fresh and new ideas, and creative and unconventional methods to solve problems and challenges (Germak 2013). One item was deleted because of cross-loading, and the recorded Cronbach's alpha coefficient was 0.863; therefore, this construct can be considered valid and reliable. In contrast for the variable of self-efficacy, only two of the items originally formulated to measure this construct loaded on this construct together with one item from the helping society, relating to the extent to which an individual can relate to people 'feeling down'. Consequently, this construct is operationalised as the extent to which individuals do not feel inadequate or fear failure, yet can still relate (and not feel superior) to individuals who are feeling forlorn.

Finally, the scales to measure the intention to become a social entrepreneur were predominately derived from Urban and Tiese (2015) and were operationalised as the extent to which the respondents find a career as a social entrepreneur attractive and intend to become a social entrepreneur. The reliability of the construct was good, with a Cronbach's alpha score of 0.865 .

\section{Reformulation of the hypotheses}

As mentioned above, the constructs of helping society split into three separate constructs and were named as helping society (connected), helping society (humanity) and helping society (empathy). Consequently, $\mathrm{H} 2$ was no longer relevant deleted and three hypotheses formulated in its place:

H2.1: Helping society (connected) will have a significant influence on the intention to become a social entrepreneur.

H2.2: Helping society (humanity) will have a significant influence on the intention to become a social entrepreneur.

H2.3: Helping society (empathy) will have a significant influence on the intention to become a social entrepreneur.

In addition $\mathrm{H} 6, \mathrm{H} 7$ and $\mathrm{H} 8$ were amended to substitute the construct helping society with helping society (connected), helping society (humanity) and helping society (empathy).

\section{Hierarchical regression analysis}

Prior to conducing a hierarchical multiple regression, the relevant assumptions of this statistical analysis were considered. Firstly, the assumption of singularity was met by all the hypothesised variables as the moderating variables (gender, parents own business, relatives own business, run own business, individualism or collectivism), independent variables (helping society (connected); need for achievement; innovation; closeness to social problem; helping society (humanity); helping society (empathy); self-efficacy) were not a combination of other independent variables.

An examination of the correlations revealed that no independent variables were highly correlated. In addition, the collinearity statistics (i.e. tolerance and the variance inflation factor [VIF]) were all within acceptable limits, so the assumption of multicollinearity was deemed to have been met. No extreme univariate outliers (in the initial data screening) were observed, and an examination of the Mahalanobis distance scores indicated no multivariate outliers. In addition, residual and scatter plots were viewed, and it can be concluded that the assumptions of normality, linearity and homoscedasticity were all satisfied (Hair et al. 2010).

A four-stage hierarchical multiple regression was conducted with social entrepreneurial intention as the dependent variable. Gender was entered at stage 1 of the regression to control for socially accepted norms of the gender roles within South African society. Three dummy variables, measuring whether or not the respondent had (1) parents who had owned their own business (parents own business) and/or (2) other relatives who had owned their own businesses (relatives own business) and/or (3) who had been in their own business (run own business), were entered at the second stage, and in the third stage the two cultural variables (individualism and collectivism) were entered. In stage 4 , the independent variables (helping society (connected); need for achievement; innovation; closeness to social problem; helping society (humanity); helping society (empathy); self-efficacy) were entered.

The hierarchical multiple regression output revealed that in model 1 (Table 2), gender significantly contributed to the regression model, $F(1,191)=8.621, p<0.01(0.006)$ and accounted for $4.3 \%$ of the variation in social entrepreneurial intention. Model 2 introduced the variables relating to previous entrepreneurial experience (parents own business, relatives own business, run own business) and explained an additional $1.1 \%$ of the variance although the change in the $R^{2}$ was not significant $F_{\text {change }}(3,188)=0.602, p>0.05(0.614)$. However, if one considers Table 3 (ANOVA), it is apparent that while the change in the variance explained is not significant, model 2 as a whole is still significant $F(4,188)=$ $2.593, p<0.05$ (0.038). Introducing culture (model 3) explained an additional $16.8 \%$ of the variance, which was also significant $F_{\text {change }}(2,186)=19.972, p<0.001(0.000)$. In the final model, the only control variables that were significant were gender (standardised beta $=0.158, p<0.05$ ) and individualism (beta $=0.141, p<0.05)$. Lastly, with model 4 the balance of the variables was introduced, explaining an additional $21 \%$ of the variance $F_{\text {change }}(7,179)=9.395, p<0.001(0.000)$.

The results presented in Tables 2 and 3 suggest that gender will have a significant moderating influence on the antecedents of the intention to start a social entrepreneurship business, as will culture (defined here using the dimensions 
TABLE 2: Model summary.

\begin{tabular}{|c|c|c|c|c|c|c|c|c|c|}
\hline \multirow[t]{2}{*}{ Model } & \multirow[t]{2}{*}{$R$} & \multirow[t]{2}{*}{$R^{2}$} & \multirow[t]{2}{*}{ Adjusted $R^{2}$} & \multirow{2}{*}{$\begin{array}{l}\text { Standard error } \\
\text { of the estimate }\end{array}$} & \multicolumn{5}{|c|}{ Change statistics } \\
\hline & & & & & $R^{2}$ change & $F$ change & $d f 1$ & $d f 2$ & $\begin{array}{c}\text { Significant } F \\
\text { change }\end{array}$ \\
\hline 1 & $0.208 \ddagger$ & 0.043 & 0.038 & 6.12194 & 0.043 & 8.621 & 1 & 191 & 0.004 \\
\hline 2 & $0.229 \S$ & 0.052 & 0.032 & 6.14115 & 0.009 & 0.602 & 3 & 188 & 0.614 \\
\hline 3 & 0.469 & 0.220 & 0.195 & 5.60182 & 0.168 & 19.972 & 2 & 186 & 0.000 \\
\hline 4 & $0.655 \dagger$ & 0.429 & 0.388 & 4.88330 & 0.210 & 9.395 & 7 & 179 & 0.000 \\
\hline
\end{tabular}

$\dagger$, Dependent variable: Intention to become a social entrepreneur.

$\$$, Predictors: (Constant), gender.

$\S$, Predictors: (Constant), gender, parents own business, relatives own business, run own business.

I. Predictors: (Constant), gender, parents own business, relatives own business, run own business, individualism, collectivism.

$\dagger$, Predictors: (Constant), gender, parents own business, relatives own business, run own business, individualism, collectivism; helping society (connected); need for achievement; innovation; closeness to social problem; helping society (humanity); helping society (empathy); self-efficacy.

TABLE 3: Analysis of variance. $\dagger$

\begin{tabular}{|c|c|c|c|c|c|c|}
\hline \multicolumn{2}{|c|}{ Model } & \multirow{2}{*}{$\frac{\text { Sum of squares }}{323.081}$} & \multirow{2}{*}{$\frac{d f}{1}$} & \multirow{2}{*}{$\begin{array}{c}\text { Mean square } \\
323.081\end{array}$} & \multirow{2}{*}{$\begin{array}{c}\boldsymbol{F} \\
8.621\end{array}$} & \multirow{2}{*}{$\frac{\text { Significant }}{0.004 \$}$} \\
\hline 1 & Regression & & & & & \\
\hline & Residual & 7158.315 & 191 & 37.478 & - & - \\
\hline & Total & 7481.396 & 192 & - & - & - \\
\hline \multirow[t]{3}{*}{2} & Regression & 391.207 & 4 & 97.802 & 2.593 & $0.038 \S$ \\
\hline & Residual & 7090.189 & 188 & 37.714 & - & - \\
\hline & Total & 7481.396 & 192 & - & - & - \\
\hline \multirow[t]{3}{*}{3} & Regression & 1644.650 & 6 & 274.108 & 8.735 & 0.000 ฯ \\
\hline & Residual & 5836.746 & 186 & 31.380 & - & - \\
\hline & Total & 7481.396 & 192 & - & - & - \\
\hline \multirow[t]{3}{*}{4} & Regression & 3212.858 & 13 & 247.143 & 10.364 & $0.000 \dagger \dagger$ \\
\hline & Residual & 4268.538 & 179 & 23.847 & - & - \\
\hline & Total & 7481.396 & 192 & - & - & - \\
\hline
\end{tabular}

$\dagger$, Dependent variable: Intention to become a social entrepreneur.

$\$$, Predictors: (Constant), gender.

$\S$, Predictors: (Constant), gender, parents own business, relatives own business, run own business.

I. Predictors: (Constant), gender, parents own business, relatives own business, run own business, individualism, collectivism.

$\dagger$, Predictors: (Constant), gender, parents own business, relatives own business, run own business, individualism, collectivism; helping society (connected); need for achievement; innovation; closeness to social problem; helping society (humanity); helping society (empathy); self-efficacy.

of individualism and collectivism). As such, $\mathrm{H} 6$ and $\mathrm{H} 7$ are supported. However, the results in respect of an entrepreneurial background are inconclusive and thus $\mathrm{H} 8$ is not supported.

In the final regression (Table 4) model, we found innovation to be positively (standardised beta $=0.439$ ) and significantly (at the 0.01 level) related to the intention to become a social entrepreneur and as such $\mathrm{H} 4$ is supported. This finding also confirms many previous studies, which found that innovation positively influenced the intention to engage in entrepreneurial activities (e.g. Germak \& Lehner 2013; Ionescu 2015; Praszkier \& Novak 2012).

The standardised coefficient for closeness to social problem is negative (beta $=-0.156$ ) and significant at the 0.001 level, which supports H1. The significant relationship between the extent to which an individual is close to a social problem is consistent with previous research (Germak \& Robinson 2014; Wong \& Tang 2007). These were the only significant relationships between the antecedents and the intention to become a social entrepreneur revealed by the results in Table 4.

\section{Discussion}

Although entrepreneurship is critical for the long-term success and growth prospects of most countries, social entrepreneurship seeks to address areas of social and environmental need neglected by governments and other agencies while at the same time making an economic contribution. Although NGOs (and other agencies) have traditionally filled this role in African countries, foreign governments and philanthropic agencies are increasingly suffering from donor fatigue, leaving many marginalised communities without any support (Smith et al. 2012). Consequently, it is a significant research problem to identify the factors that drive the intention to become a social entrepreneur.

To address this issue, this study referred to a number of the theories which have been advanced as a way of understanding the intention to become a social entrepreneur. Specifically, this study found that innovation had a significant relationship influence on the intention to become a social entrepreneur. This finding is consistent with many other studies (Germak \& Lehner 2013; Ionescu 2015; Praszkier \& Novak 2012) which propose that being innovative is an important element in the creation of new social enterprises. Indeed, it is argued that, because of the complexity of juxtaposing a viable financial model with a social mission, being innovative is even more important in social entrepreneurship than within the context of traditional entrepreneurship.

The findings of the study reveal that the extent to which individuals feel close to a social problem will also have a 


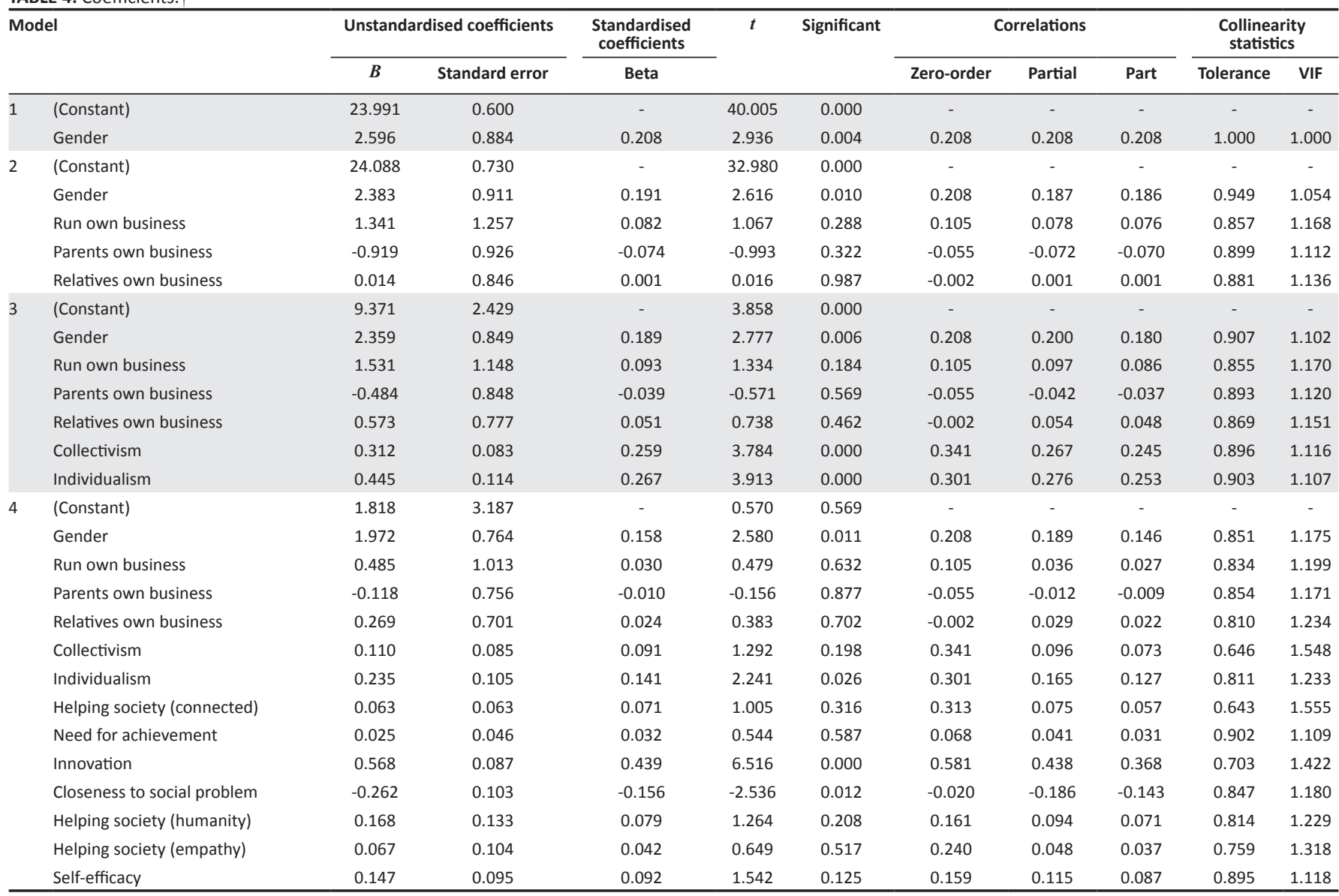

$\mathrm{VIF}$, variance inflation factor.

$\dagger$, Dependent variable: Intention to become a social entrepreneur.

material impact on the extent to which students intend to become a social entrepreneur. This is consistent with the findings of Germak and Robinson (2013) and Drennan et al. (2015), which found that there is a link between a disadvantaged or difficult background and an entrepreneurial intention. What also adds resonance to this corroboration is that these two studies took very different approaches in different contexts. Germak and Robinson (2013) followed a qualitative approach with 'mature' respondents, whereas Drennan et al. (2015) did a quantitative analysis using firstyear students (albeit both from developed countries).

There have, however, been a number of calls for the inclusion of moderating variables to improve both the limited exploratory power and inconsistencies among studies. Although this study found that culture and gender both have a moderating influence on the antecedents to the formation of an intention to start an entrepreneurial venture, the dimensions of individualism or collectivism, as defined by Hofstede (1980), were used as a proxy for culture. Although this study did confirm the findings of extant research (Pinillos \& Reyes 2011; Tiessen 1997; Urban 2007), the level of economic development may also have an influence on the nature and extent of the influence. As such, this study does confirm that individualism or collectivism does moderate the influence of the antecedents on the intention to become a social entrepreneur, but it does not account for the influence of economic development.
The findings that gender moderates the relationship between the antecedents and the intention to become a social entrepreneur have a number of implications. Men are motivated to become entrepreneurs by 'pull factors' such as the perception that entrepreneurship will give them an opportunity to control their own destiny and be able to earn an uncapped income. This differs from women, who are usually driven into entrepreneurship by 'push' factors such as gender prejudice (Gupta et al. 2009), frustration, the difficulty in balancing work and family commitments or, often, in developing countries, poverty (Buttner \& Moore 1997). Consequently, the impact of gender on the intention to become a social entrepreneur may be more pronounced for younger people than for older individuals when the 'push factors' associated with life experiences have not yet manifested themselves. The findings suggest that entrepreneurship education, targeted specifically at women, may be an intervention that is required to educate women about social entrepreneurship as a feasible career choice.

\section{Limitations and future research}

Gender has been identified as having a significant influence which may moderate the antecedents influencing the intention to become a social entrepreneur. However, it is postulated that the influence of this construct may vary over time, as the 'push' factors associated with the changing 
attitudes of women come into play. As such a study comparing the attitudes of young women (towards intention) with that of more mature women could be a feasible research area, as would a longitudinal study mapping out the changing attitudes of women over time.

Culture may play an important part in how gender moderates the relationship between the antecedents to the formation of intention. As such alternative research methodologies could be a way of examining these differences. Qualitative research methodologies could allow research to 'drill down' in respect of the complex interaction between gender, family influences and the broader cultural influences.

The results reveal that attitudes towards social entrepreneurship emerge from individuals' being close to the social problem. If this type of experience is well understood, it might well influence the way social entrepreneurship education is envisaged (Drennan et al. 2015). In particular, entrepreneurial curricula might consider including aspects necessary for self-employment emerging from such an experience, such as resourcefulness, resilience and independence. An in-depth qualitative study would allow researchers to interrogate the nature of this experience and its nexus with their intention to become a social entrepreneur.

\section{Implications for policy and practice}

The study findings reveal that the extent to which individuals are close to a social problem can play a significant role in forming an intention to become a social entrepreneur. Similarly, the results imply that culture (defined in this study as individualism or collectivism) will also play a moderating role with students in choosing social entrepreneurship as a career. This suggests that in a multi-cultural society, such as South Africa, the education curriculum needs to promote a dialogue so that different cultural groups understand each other's values and perspectives.

South Africa is characterised by one of the most unequal societies in the world. This divide is also reflected in the character of its institutions including universities. This suggests that there needs to be more collaboration and dialogue across both faculty and students so that all stakeholders appreciate the economic and social challenges faced by the broader society. These efforts should be across different disciplines to facilitate an education system that is equipped to deal with the unique socio-economic challenges encountered in South Africa.

\section{Conclusion}

The purpose of this study was to investigate the extent to which antecedents identified in the literature were moderated by gender, family entrepreneurial background and culture. The study confirmed that gender and culture (defined in this study as individualism and/or collectivism) do have a moderating influence on the antecedents to the formation of an intention to become a social entrepreneur. This implies that policy makers, seeking to encourage social entrepreneurship in South Africa, should take into consideration the contextual elements of the student cohort.

This research can be considered an exploratory study and should be critically interpreted because it does not take into account many of the dynamics inherent in the formulation of an intention to become a social entrepreneur. In addition, the sample was drawn from the student body of one university and a more inclusive sample would allow for a more robust interpretation of the results. Nevertheless this study does make a valuable contribution to understanding the complex interaction between the factors initiating an intention to become a social entrepreneur among South African youth.

\section{Acknowledgements}

The author acknowledges the contribution of the following who helped collect the data: Comfort Makwanya, Rumbidzai Ruth Masunda, Sinazo Magatya, Lihle Calu, Kanyisile Mandla, Khulile Mantshongo, Ziyanda Poswa and Nombuso Zamane.

\section{Competing interests}

The author declares that he has no financial or personal relationships that may have inappropriately influenced him in writing this article.

\section{Disclaimer}

The views expressed in this article are that of the author and do not reflect an official position of the University of Fort Hare or any other institution.

\section{References}

Acs, Z., 2006, 'How is entrepreneurship good for economic growth?' Innovations: Technology, Governance, Globalization 1(1), 97-107. https://doi.org/10.1162/ itgg.2006.1.1.97

Ajzen, I., 1988, Attitudes, personality, and behavior, Dorsey Press, Homewood, IL.

Ajzen, I., 1991, 'The theory of planned behaviour', Organizational Behaviour and Human Decision Processes 50(2), 179-211. https://doi.org/10.1016/07495978(91)90020-T

Ajzen, I., 2002, 'Perceived behavioral control, self-efficacy, locus of control and the theory of planned behavior', Journal of Applied Social Psychology 32, 665-683. https://doi.org/10.1111/j.1559-1816.2002.tb00236.x

Ajzen, I., 2011, 'The theory of planned behaviour: Reactions and reflections', Psychology and Health 26, 1113-1127. https://doi.org/10.1080/08870446.2011. 613995

Aliaga, C., 2006, 'How is the time of women and men distributed in Europe?' Statistics in Focus, 14, 1-11.

Bagheri, A. \& Pihie, Z.A.L., 2010, 'Role of family in entrepreneurial leadership development of university students', World Applied Sciences Journal 11(4), 434-442.

Bahrami, S., 2014, 'Entrepreneurship intentions and perceptions in the UAE: A study of moderating effects of gender, culture and family', International Journal of Small Business and Entrepreneurship Research 2(4), 37-50.

Bandura, A., 1977, Social learning theory, General Learning Press, New York.

Bandura, A., 1986, Social foundation of thought and action. A social cognitive theory, Englewood Cliffs, NJ, Prentice Hall.

Bandura, A., 1997, Self-efficacy: The exercise of control, Freeman and Company, New York.

Bandura, A., 2001, 'Social cognitive theory: An argentic perspective', Annual Review of Psychology 52(1), 1-26. https://doi.org/10.1146/annurev.psych.52.1.1 
Baum, J.R. Frese, M. \& Baron, R.A. (eds.), 2007, The psychology of entrepreneurship, Erlbaum, Mahwah, NJ.

Bird, B., 1988, 'Implementing entrepreneurial ideas: The case for intention', Academy of Management Review 13, 442-453. https://doi.org/10.5465/amr.1988.4306970

Birley, S. \& Westhead, P., 1994, 'A taxonomy of business start-up reasons and their impact on firm growth and size', Journal of Business Venturing $9(1), 7-31$. https:// doi.org/10.1016/0883-9026(94)90024-8

Boluk, K.A. \& Mottiar, Z., 2014, 'Motivations of social entrepreneurs: Blurring the social contribution and profits dichotomy', Social Enterprise Journal 10(1), 53-68. https://doi.org/10.1108/SEJ-01-2013-0001

Bornstein, D. \& Davis, S., 2010, Social entrepreneurship: What everyone needs to know, Oxford University Press, New York.

Bouchard, M.J., 2012, 'Social innovation, an analytical grid for understanding the social economy: The example of the Quebec housing sector', Service Business 6, 47-59. https://doi.org/10.1007/s11628-011-0123-9

Bruton, G.D. \& Ahlstrom, D., 2003, 'An institutional view of China's venture capital industry: Explaining the differences between China and the west', Journal of Business Venturing 18(2), 233-259. https://doi.org/10.1016/S0883-9026 (02)00079-4

Buttner, E.H. \& Moore, D.P., 1997, 'Women's organizational exodus to entrepreneurship: Self-reported motivations and correlates with success', Journa of Small Business Management 35(1), 34-46.

Carsrud, A. \& Brannback, M., 2011, 'Entrepreneurial motivations: What do we still need to know?' Journal of Small Business Management 49(1), 9-26.

Certo, S.T. \& Miller, T., 2008, 'Social entrepreneurship: Key issues and concepts', Business Horizons 51, 267-271. https://doi.org/10.1016/j.bushor.2008.02.009

Cope, J., 2005, 'Toward a dynamic learning perspective of entrepreneurship', Entrepreneurship theory and practice 29(4), 373-397. https://doi. org/10.1111/j.1540-6520.2005.00090.x

Dacin, M., Dacin, P. \& Tracey, P., 2011, 'Social entrepreneurship: A critique and future directions', Organization Science 22(5), 1203-1213. https://doi.org/10.1287/ orsc. 1100.0620

Drennan, J., Kennedy, J. \& Renfrow, P., 2015, 'Impact of childhood experiences on the development of entrepreneurial intentions', The International Journal of Entrepreneurship and Innovation 6(4), 231-238. https://doi.org/10. Entrepreneurship and In

Fielden, S.L. \& Davidson, M. (eds.), 2005, International handbook of women and small business entrepreneurship, Edward Elgar Publishing, Northampton, MA.

Germak, A.J., 2013, 'Social entrepreneurship motivation: A quantitative analysis of nascent social entrepreneurs' in EMES-SOCENT Conference Selected Papers, July 1-4, 2013, pp. 13-69.

Germak, A.J. \& Lehner, O.M., 2013, 'The need for achievement (and other antecedents. as drivers of social entrepreneurship', International Journal of Socia Entrepreneurship and Innovation 3(3), 214-229.

Germak, A.J. \& Robinson, J.A., 2014, 'Exploring the motivation of nascent social entrepreneurs', Journal of Social Entrepreneurship 5(1), 5-21. https://doi.org/ $10.4337 / 9781845425586$

Gird, A. \& Bagraim, J.J., 2008, 'The theory of planned behaviour as predictor of entrepreneurial intent amongst final-year university students', South African Journal of Psychology 38(4), 711-724. https://doi.org/10.1177/0081246308 03800410

Gupta, V.K., Turban, D.B., Wasti, S.A. \& Sikdar, A., 2009, 'The role of gender stereotypes in perceptions of entrepreneurs and intentions to become an entrepreneur' Entrepreneurship: Theory and Practice 33(2), 397-417. https://doi.org/10.1111/ j.1540-6520.2009.00296.x

Hair, J.F., Black, W.C., Babin, B.J. \& Anderson, R.E., 2010, Multivariate data analysis, 7th edn., Prentice hall, Upper Saddle River, NJ.

Halcombe, R.G., 1998, 'Entrepreneurship and economic growth', Quarterly Journal of Austrian Economics 1(2), 45-62. https://doi.org/10.1007/s12113-998-1008-1

Harris, M.L. \& Gibson, S.G., 2008, 'Examining the entrepreneurial attitudes of US business students', Education and Training 50(7), 568-581. https://doi.org/ 10.1108/00400910810909036

Hart, S.L., 2005, 'Innovation, creative destruction and sustainability', Research Technology Management 45(5), 21-33. https://doi.org/10.1080/08956308.2005. 11657334

Hayton, J.C., George, G. \& Zahra, S.A., 2002, 'National culture and entrepreneurship A review of behavioral research', Entrepreneurship Theory and Practice 26(4), 33. https://doi.org/10.1177/104225870202600403

Henry, C., Foss, L. \& Ahl, H., 2016, 'Gender and entrepreneurship research: A review of methodological approaches', International Small Business Journal 34(3), 217-241. https://doi.org/10.1177/0266242614549779

Herrington, M., Kew, J. \& Kew, P., 2010, Tracking entrepreneurship in South Africa: A GEM perspective, SA GEM Report, Graduate School of Business, Cape Town.

Hervieux, C. \& Voltan, A.J., 2018 'Framing social problems in social entrepreneurship', Journal of Business Ethics 151(2), 279-293. https://doi.org/10.1007/s10551-0163252-1

Hofstede, G. \& Bond, M., 1988, 'The Confucius connection: From cultural roots to economic growth', Organizational Dynamics 16(4), 4-21. https://dol. org/10.1016/0090-2616(88)90009-5

Hofstede, G., 1980, Culture consequences: International difference in work-related values, Sage Publications, Beverly Hills, CA.

Hofstede, G., 2001, 'Culture's recent consequences: Using Dimension scores in theory and research', International Journal of Cross-Cultural Management 1(1), 11-17. https://doi.org/10.1177/147059580111002
Illingworth, L., 2015, 'Why does South Africa have so few entrepreneurs?' Finweek, 05 January, pp. 54-55.

Ionescu, C., 2015, 'About the conceptualization of social innovation', Theoretical and Applied Economics 22(3), 53-62.

Irengun, O. \& Arikboga, S., 2015, 'The effect of personality traits on social entrepreneurship intentions: A field research', Social and Behavioural Sciences 195, 1186-1195. https://doi.org/10.1016/j.sbspro.2015.06.172

Johnson, S., 2000, 'Literature review on social entrepreneurship', Canadian Centre for Social Entrepreneurship 16, 1-4.

Jolliffe, I., 2002, Principal component analysis, John Wiley and Sons, New York.

Kaiser, H.F., 1960, 'The application of electronic computers to factor analysis', Educational and Psychological Measurement 20(1), 141-151. https://doi.org/10. $1177 / 001316446002000116$

Karhunen, P. \& Ledyaeva, S., 2010, 'Determinants of entrepreneurial interest and risk tolerance among Russian university students: An empirical study', Journal of Enterprising Culture 18(3), 229-263. https://doi.org/10.1142/S021849581000 0574

Krueger, N.F., Reilly, M.D. \& Carsrud, A.L., 2000, 'Competing models of entrepreneuria intentions', Journal of Business Venturing 15(5-6), 411-432. https://doi. org/10.1016/S0883-9026(98)00033-0

Lazenby, J. \& Machaba, R., 2011, 'A descriptive analysis of Gauteng entrepreneurs with respect to the old debate of whether entrepreneurship is an inborn quality or can be learnt', International Journal of Business and Social Science 2(21), 72-80.

Maas, G. \& Herrington, M., 2006, Global entrepreneurship monitor South African executive report (online), viewed 10 May 2016, from http://www.gbs.nct.ac.za/ gbswebb/userfiles/gemsouthafrica2000pdf.

Mahadea, D, Ramroop, S. \& Zewotir, T., 2011, 'Assessing entrepreneurship perceptions of high school learners in Pietermaritzburg, KwaZulu-Natal', South African Journal of Economic and Management Sciences 14(1), 66-79. https://doi.org/10.4102/ sajems.v14i1.59

Mair, J. \& Marti, I., 2006, 'Social entrepreneurship research: A source of explanation prediction and delight', Journal of World Business 41, 36-44. https://doi. org/10.1016/j.jwb.2005.09.002

Mair, J. \& Noboa, E., 2006, 'Social entrepreneurship: How intentions to create a social venture are formed', in J. Mair, J. Robinson \& K. Hockerts (eds.), Socia entrepreneurship, pp. 121-135, Palgrave Macmillan, New York.

Manyaka, S.J., 2015, 'Social entrepreneurship: A solution for transforming the disadvantaged community of Nellmapius', Journal of Theological Studies 71(3), 1-7. https://doi.org/10.4102/hts.v71i3.2821

Maslow, A.H., 1943, 'A theory of human motivation', Psychological Review 50(4), 370 396. https://doi.org/10.1037/h0054346

Matthews, C.H. \& Moser, S.B., 1995, 'The impact of family background and gender on interest in small firm ownership: A longitudinal study' in proceedings of the ICSB 40th World conference, Sydney, June 19-21, 1995, pp. 18-21.

McGrath, R.G., Macmillan, I.C. \& Scheinberg, S., 1992, 'Elitists, risk takers and rugged individualists? An exploratory analysis of cultural differences between entrepreneurs and non-entrepreneurs', Journal of Business Venturing 7, 115-135. https://doi.org/10.1016/0883-9026(92)90008-F

Memani, M.M. \& Fields, Z., 2014, 'Factors influencing the development of productive entrepreneurial behaviour among university students', Journal of Contemporary Management 11, 287-301.

Miller, T.L., Grimes, M.G., McMullen, J.S. \&. Vogus, T.J., 2012, 'Venturing for others with heart and head: How compassion encourages social entrepreneurship' Academy of Management Review 37(4), 616-640. https://doi.org/10.5465/ Academy of $M$

Morris, M.H., Davis, D.L. \& Allen, J.W., 1993, 'Fostering corporate entrepreneurship: Cross-cultural comparisons of the importance of individualism versus collectivism', Journal of International Business Studies 25(1), 65-89.

Mueller, S.L. \& Thomas, A.S., 2001, 'Culture and entrepreneurial potential: A nine country study of locus of control and innovativeness', Journal of Business Venturing 16, 51-75. https://doi.org/10.1016/S0883-9026(99)00039-7

Nattrass, N. \& Seekings, J., 2001, 'Two nations? Race and economic inequality in South Africa today', Daedalus 130(1), 45-70.

Nga, J.K.H. \& Shamuganathan, G., 2010, 'The influence of personality traits and demographic factors on social entrepreneurship start up intentions', Journal of Business Ethics 95(2), 259-282. https://doi.org/10.1007/s10551-009-0358-8

Nyström, K., 2009, 'Entry, market turbulence and industry employment growth', Empirica 36(3), 293-308. https://doi.org/10.1007/s10663-008-9086-z

Odhiambo, N.M., 2009, 'Finance-growth-poverty nexus in South Africa: A dynamic causality linkage' The Journal of Socio-Economics 38, 320-325. https://doi. org/10.1016/j.socec.2008.12.006

Pinillos, M.J. \& Reyes, L., 2011, 'Relationship between individualist-collectivist culture and entrepreneurial activity: Evidence from global entrepreneurship monitor data', Journal of Small Business Economics 37(1), 23-37. https://doi.org/10.1007/ s11187-009-9230-6

Prabhu, G.N., 1999, 'Social entrepreneurship leadership', Career Development International 4(3), 140-145. https://doi.org/10.1108/13620439910262796

Praszkier, R. \& Novak, A., 2012, Social entrepreneurship: Theory and practice, Cambridge University Press, New York.

Raes, F., Pommier, E., Neff, K.D. \& Van Gucht, D., 2011, 'Construction and factorial validation of a short form of the self-compassion scale', Clinical Psychology and Psychotherapy 18(3), 250-255. https://doi.org/10.1002/cpp.702 
Rametse, N. \& Shah, H., 2013, 'Investigating social entrepreneurship in developing countries', World Review of Business Research 3(2), 95-112.

Scherer, R.F., Adams, J.S., Carley, S. \& Wiebe, F.A., 1989, 'Role model performance effects on development of entrepreneurial career preference', Entrepreneurship: Theory \& Practice 13(3), 53-71. https://doi.org/10.1177/104225878901300306

Seelos, C. \& Mair, J., 2005, 'Social entrepreneurship: Creating new business models to serve the poor', Business Horizons 48, 241-246. https://doi.org/10.1016/j. bushor.2004.11.006

Shapero, A. \& Sokol, L., 1982, 'Social dimensions of entrepreneurship', in C.A. Kent, D.L. Sextonn \& K.H. Vesper (eds.), The Encyclopaedia of entrepreneurship, pp. 72-79, Prentice-Hall, Englewood Cliffs, NJ.

Shaw, E. \& Carter, S., 2007, 'Social entrepreneurship: Theoretical antecedents and empirical analysis of the entrepreneurial processes and outcomes', Journal of Small Business and Economic Development 14(13), 418-434. https://doi. org/10.1108/14626000710773529

Shen, T., Osorio, A.E. \& Settles, A., 2017, 'Does family support matter? The influence of support factors an entrepreneurial attitudes and intentions of college students', Academy of Entrepreneurship Journal 23(1), 24-43.

Shinnar, R.S., Giacomin, O. \& Janssen, F., 2012, 'Entrepreneurial perceptions and intentions: The role of gender and culture', Entrepreneurship Theory and Practice 36(3), 465-493. https://doi.org/10.1177/0266242617704277

Shinnar, R.S., Hsu, D.K., Powell, B.C. \& Zhou, H., 2017, 'Entrepreneurial intentions and start-ups: Are women or men more likely to enact their intentions?', International Small Business Journal 36(1), 60-80. https://doi.org/10.1111/j.1540-6520. 2012.00509.x

Shittu, A.I. \& Dosunmu, Z., 2014, 'Family background and entrepreneurial intention of fresh graduates in Nigeria', Journal of Poverty, Investment and Development 5 , 7890 .

Shook, C.L., Priem, R.L. \& McGee, J.E., 2003, 'Venture creation and the enterprising individual: A review and synthesis', Journal of Management 29(3), 379-399. https://doi.org/10.1016/S0149-2063(03)00016-3

Smith, B.R., Cronley, M.L. \& Barr, T.F., 2012, 'Funding implications of social enterprise: The role of mission consistency, entrepreneurial competence, and attitude toward social enterprise on donor behaviour', Journal of Public Policy \& Marketing 31(1) 142-157. https://doi.org/10.1509/jppm.11.033

Soomro, B.A. \& Shah, N., 2015, 'Developing attitudes and intentions among potential entrepreneurs', Journal of Enterprise Information Management 28(2), 304-322. https://doi.org/10.1108/JEIM-07-2014-0070

Terjesen, S., Lepoutre, J., Justo, R. \& Bosma, N., 2009, Global entrepreneurship monitor report on social entrepreneurship, Global Entrepreneurship Research Association (GERA), Babson Park, MA.

Tiessen, J.H., 1997 'Individualism, collectivism, and entrepreneurship: A framework for international comparative research', Journal of Business Venturing 12(5) 367-384. https://doi.org/10.1016/S0883-9026(97)81199-8

Tom, M., 2016, Presentation to commission on higher education and training University of Fort Hare, 25 November 2016, viewed 20 March 2018, from http:// www.justice.gov.za/commissions/feeshet/hearings/set4/set4-d09-25Nov2016profmvuyotom-forthare.pdf.
Toma, S., Grigore, A. \& Marinescu, P., 2014, 'Economic development and entrepreneurship', Procedia Economics and Finance 8, 436-443. https://doi. org/10.1016/S2212-5671(14)00111-7

Triandis, H.C. \& Su, M.E., 2002, 'Cultural influences on personality', Annual Review of Psychology 53, 133-160. https://doi.org/10.1146/annurev.psych.53.100901.13 5200

Turker, D. \& Selçuk, S., 2009, 'Which factors affect entrepreneurial intention of university students?', Journal of European Industrial Training 33(2), 142-159. https://doi.org/10.1108/03090590910939049

Urban, B., 2006, 'Entrepreneurship in the rainbow nation: Effect of cultural values and ESE on intentions', Journal of Developmental Entrepreneurship 11(03), 171-186. https://doi.org/10.1142/S1084946706000386

Urban, B., 2007, 'A framework for understanding the role of culture in entrepreneurship', Acta Commercii 7(1), 82-95. https://doi.org/10.4102/ac. v7i1.13

Urban, B., 2010, 'A gender perspective on career preferences and entrepreneurial selfefficacy', Journal of Human Resource and Management 8(1), 1-8. https://doi. org/10.4102/sajhrm.v8i1.293

Urban, B., 2012, 'A metacognitive approach to explaining entrepreneurial intentions', Management Dynamics 21(2), 16-33.

Urban, B., 2013, 'Influence of the institutional environment on entrepreneurial intentions in an emerging economy'. The International Journal of Entrepreneurship and Innovation 14(3), 179-191. https://doi.org/10.5367/ijei.2013.0122

Urban, B., 2015, 'Evaluation of social enterprise outcomes and self-efficacy', International Journal of Social Economics 42(2), 163-178. https://doi.org/10. 1108/IJSE-03-2013-0071

Urban, B. \& Teise, H., 2015, 'Antecedents to social entrepreneurship intentions: An empirical study in South Africa', Management Dynamics 24(2), 36-52.

Van Praag, C.M. \& Versloot, P.H., 2007, 'What is the value of entrepreneurship? A review of recent research', Journal of Small Business Economics 29(4), 351-382. https://doi.org/10.1007/s11187-007-9074-x

Wong, L. \& Tang, J., 2007, 'Dilemmas confronting social entrepreneurs: Care homes for elderly people in Chinese cities', Pacific Affairs 79(4), 623-637. https://doi. org/10.5509/2006794623

Woolard, I. \& Leibbrandt, M., 1999, Measuring poverty in South Africa, Development Policy Research Unit, Working Paper 99/33, University of Cape Town, viewed 18 April 2018, from http://open.uct.ac.za/bitstream/handle/11427/7237/DPRU WP99-033.pdf?sequence $=1$.

World Bank, 2017, The World Bank in South Africa: Overview (3 May 2017), viewed 18 April 2018, from http://www.worldbank.org/en/country/southafrica/overview.

Wu, S., Matthews, L. \& Dagher, G.K., 2007, 'Need for achievement, business goals, and entrepreneurial persistence', Management Research News 30, 928-941. https:// doi.org/10.1108/01409170710833358

Zahra, S., Shaker, A., Gedajlovic, E., Neubaum, D.O. \& Shulman, J.M., 2009, 'A typology of social entrepreneurs: Motives search processes and ethical challenges', Journal of Business Venturing 24, 519-532. https://doi.org/10.1016/j.jbusvent.2008. 04.007 


\section{Appendix 1}

TABLE 1-A1: Items used in the study.

\begin{tabular}{|c|c|}
\hline Code & Label \\
\hline HS3K & $\begin{array}{l}\text { If I see someone going through a difficult time, I try to be caring toward } \\
\text { that person }\end{array}$ \\
\hline HS1S & I am emotionally connected to people in pain \\
\hline HS4K & I like to be there for others in times of difficulty \\
\hline HS2S & I relate to others when they tell me their problems \\
\hline HS12K & When others feel sadness, I try to reach out to them \\
\hline HS11S & I can really connect with other people when they're suffering \\
\hline HS8K & My heart goes out to people who are unhappy \\
\hline $\mathrm{EI} 2$ & Owning my own social venture would be a good career choice \\
\hline EI4 & I intend to set up a social venture in the future \\
\hline EI3 & Being a social entrepreneur is more appealing than having a job \\
\hline EI5 & I am always searching for social venture opportunities \\
\hline El1 & Becoming a social entrepreneur interests me very much \\
\hline NA5 & $\begin{array}{l}\text { I put little time and effort into my work/When I take on a project, I give } \\
\text { everything }\end{array}$ \\
\hline NA6 & I am not motivated to succeed/I want to be the very best of myself \\
\hline NA2 & $\begin{array}{l}\text { I believe that I am average/I think that I am destined for extraordinary } \\
\text { accomplishments }\end{array}$ \\
\hline NA7 & $\begin{array}{l}\text { I do as little as possible whenever possible/I continue until I think } \\
\text { everything is perfect }\end{array}$ \\
\hline NA4 & $\begin{array}{l}\text { I just do enough work to get by/I always do more than what is expected of } \\
\text { me }\end{array}$ \\
\hline NA3 & $\begin{array}{l}\text { I concentrate more on short-term and daily tasks/I set long-term goals for } \\
\text { myself }\end{array}$ \\
\hline INN4 & I think I have a lot of fresh ideas \\
\hline INN3 & I come up with creative solutions when confronted with problems \\
\hline INN5 & I like to try unconventional solutions to challenges \\
\hline INN1 & I have a lot of new ideas to solve old problem \\
\hline CSP7 & $\begin{array}{l}\text { Poor people have the same intelligence as the rest of society; they may } \\
\text { just have less education }\end{array}$ \\
\hline CSP6 & Poor people have the same set of values as other people \\
\hline CSP4 & At their core, poor people are the same as me \\
\hline $\mathrm{HA6H}$ & Everyone feels down sometime it is part of being human \\
\hline $\mathrm{HS7H}$ & $\begin{array}{l}\text { It is important to recognise that all people have weaknesses and no one's } \\
\text { perfect }\end{array}$ \\
\hline $\mathrm{HS9H}$ & $\begin{array}{l}\text { Despite my differences with others I know that everyone feels pain just } \\
\text { like me }\end{array}$ \\
\hline CSP2 & Poor people are generally honest \\
\hline CSP3 & I can relate to poor people \\
\hline CSP1RS & Poor people are different from the rest of society (reverse scored) \\
\hline SA5RS & I am bothered by fears of being inadequate (reverse scored) \\
\hline SA2RS & I fear failure (reverse scored) \\
\hline HS5SRS & $\begin{array}{l}\text { When I see someone feeling down, I feel like I cannot relate to them } \\
\text { (reverse scored) }\end{array}$ \\
\hline
\end{tabular}

